\title{
Sistem Pendukung Keputusan Pemilihan Platform E-commerce Dengan Metode Simple Additive Weighting
}

\author{
Alifiandi Nursanni Wiriadikusumah ${ }^{1}$, Fahmi Candra Permana ${ }^{2}$ \\ 1,2Prodi Pendidikan Multimedia Kampus Cibiru, Universitas Pendidikan Indonesia \\ Лl. Raya Cibiru Km 15Bandung 40393 \\ 1alifiandinursanni@upi.edu, 2fahmi.candrap@upi.edu
}

\begin{abstract}
ABSTRAK
Perkembangan dunia bisnis telah berubah dari tradisional menjadi digital, hal inilah yang menjadi dasar munculnya industri e-commerce di era ini sebagai jembatan bagi konsumen dan penjual untuk bertemu dan bertukar barang dan uang. Perkembangan e-commerce secara lokal maupun eksternal sangat pesat, karena dipicu oleh peningkatan penjualan melalui media, sehingga persaingan sangat ketat. Untuk itu, kita perlu memperhatikan alasan mengapa konsumen memilih berbelanja di perusahaan e-commerce tertentu, apa alasannya, dan jenis produk apa yang mereka kejar. Artikel ini membahas hasil dari pembuatan program aplikasi sistem pendukung keputusan dengan metode Simple Additive Weighting yang mana ini adalah suatu metode sistem pendukung keputusan untuk menghasilkan peringkat dari alternatif yang ada berdasarkan dari kriteria-kriteria yang pilihannya ditentukan oleh pengguna, dalam memilih platform e-commerce. Dalam pemilihan keputusan tentu ada faktor-faktor yang terkait, dalam penelitian sebelumnya ditemukan dimensi faktor-faktor yang terkait sebagai dasar dalam pembangunan aplikasi SPKini.
\end{abstract}

Kata kunci: SPK, e-commerce, SAW, planned behavior

\begin{abstract}
The development of the business world has changed from traditional to digital, this is the basis for the emergence of the $e^{-}$ commerce industry in this era as a bridge for consumers and sellers to meet and exchange goods and money. The development of e-commerce locally and externally is very rapid, because it is triggered by an increase in sales through the media, so the competition is very tight. For that, we need to pay attention to the reasons why consumers choose to shop atcertain e-commerce companies, what the reasons are, and what types of products they are after. This article discusses the results of making a decision support system application program with the Simple Additive Weighting method which is a decision support system method to generate a ranking of existing alternatives based on the criteria whose choices are determined by the user, in choosing an $e^{-}$ commerce platform. In the selection of decisions, of course there are related factors, in previous studies found the dimensions of the related factors as the basis for the development of this DSS application.
\end{abstract}

Keywords: DSS, e-commerce, SAW, planned behavior

\section{Pendahuluan}

Teknologi khususnya komputer telah berkembang sangat pesat dalam beberapa tahun terakhir. Di masa lalu, orang menggunakan alat tulis seperti pulpen atau pensil untuk menulis. Saat ini, penggunaan komputer dapat menggantikan penulisan manual. Cukup tekan keyboard dan huruf atau angka yang diperlukan akan muncul di layar. Generasi $\mathrm{Z}$ adalah generasi muda yang baru saja memasuki pasar tenaga kerja, yang juga dikenal sebagai iGeneration atau generasi Internet. Gen Z mirip dengan Gen Y, namun Gen Z mampu menerapkan semua aktivitas (multitasking) secara bersamaan, seperti menjalankan media sosial di ponsel, browsing di PC, dan mendengarkan musik di headphone. Segala sesuatu yang Anda lakukan terutama terkait dengan dunia maya. Generasi ini sudah akrabdengan teknologi sejak kecil, dan akrab dengan gadget canggih yang secara tidak langsung mempengaruhi kepribadian [8].

Dengan kemajuan teknologi yang terus menerus, karena kebanyakan orang memiliki tingkat mobilitas yang tinggi dalam aktivitas sehari-hari, gaya hidup sosial menjadi lebih langsung. Oleh karena itu, orang sering mencari hal-hal praktis untuk memenuhi kebutuhan sehari-hari. Berbagai kegiatan dan kegiatan telah beralih ke titik ini, menggunakan teknologi untuk mempromosikan kegiatan sehari-hari, sehingga menjadi lebih efektif dan efisien, seperti di dunia penjualan sebelumnya, cara konsumen langsung ke toko untuk membeli barang masih digunakan dalam rangka to Bagi yang tidak punya banyak waktu, tidak bisa langsung mengunjungi tokonya. Terutama konsumen cair.

Banyaknya platform E-commence yang tersedia saat ini memberi pilihan yang beragam bagi konsumen untuk berbelanja secara online dengan menikmati kelebihan dari masing-masing platform yang ditawarkan. Pada data Q4 2017 tercatat ada sekitar 57 perusahaan e-commerce yang ada di Indonesia dan darijumlah tersebut ada daftar sepuluh e commence yang paling 
banyak di kunjungi pada data triwulan 12018 dengan urutan sebagai berikut Pertama Lazada dengan pengunjung 117.6juta, Tokopedia 117.3juta, Bukalapak 93.6juta, blibli 45.9juta, shopee 34.5 juta, JDid 13.2 juta, Bhinneka 7.4 juta, Elevenia 6.3 juta, Zalora 5.2 juta dan mataharimall 4 juta [10].

Persaingan yang ketat membuat banyak orang mulai selektif terhadap e-commerce. Pemilik atau perusahaan e-commence dituntut untuk membangun sebuah website yang baik untuk menarik konsumen untuk membeli, karena dalam proses transaksi di dunia e-commence, faktor terpenting adalah kepercayaan dan manfaat yang dirasakan. Kepercayaan semacam inilah yang menjadi faktor penentu. Dalam sebuah e-commerce, setidaknya ada 3 jenis kepercayaan konsumen yang menjadi pertimbangan dalam memilih dan melakukan transaksi. Selain itu, ada faktor tambahan yaitu persepsi risiko dalam bertransaksi. mata transaksi dalam e-commerce Konsumen waktu. Berbagai faktor yang mempengaruhi keputusan pembelian itu sendiri dapat diperoleh dari faktorfaktor lain, antara lain kepercayaan, risiko, manfaat yang dirasakan konsumen, dan konsumen e-commerce yang mudah dipahami dan bermanfaat yang mempengaruhi niat beli.

Pada penelitian ini dibuat sebuah program sistem pendukung keputusan (SPK) pemilihan platform e-commerce yang dibangun berdasarkan penelitian terkaityang sebelumnya menemukan beberapa dimensi faktor yang menjadi pertimbangan konsumen dalam memilih platform e-commercedan melakukan keputusan belanja pada platform tersebut. Adapun acuan lain yang digunakan sebagai referensi dalam penelitian ini salah satunya penelitian yang dilakukan Permana dengan judul Rancang Bangun Sistem Informasi Display Jadwal Perkuliahan Kampus Upi Di Cibiru Berbasis Web [7], dijadikan sebagai referensi karena aplikasi SPK yang dibuat akan berjalan pada platform web sehingga dapat mudah diakses oleh banyak pengguna, dan memudahkan dalam proses uji coba, lalu penelitian terkait aplikasi dengan metode SAW yang dilakukan oleh Djamanin dengan judul Sistem pendukung keputusan penerimaan pegawai baru pt. pln (persero) kantor pusat dengan menggunakan metode simple additive weighting [1], kemudian penelitian oleh Eniyati dengan judul Perancangan sistem pendukung pengambilan keputusan untuk penerimaan beasiswa dengan metode SAW [2], dan oleh Fitriyani dengan judul Sistem Pendukung Keputusan Dalam Menentukan Ketua Osis Menggunakan Simple Additive Weighting [3], dijadikan sebagai acuan dalam membuat aplikasi SPK dengan metode SAW, selanjutnya ditemukan penelitian yang menjadi dasar faktorfaktor variabel terkait e-commerce dari penelitian yang ditulis oleh Suleman dengan judul Faktor penentu keputusan konsumen Indonesia memilih tempat belanja disebuah e-commerce (Theory of Planned Behavior) [10] .

\section{Metode Penelitian}

Penelitian ini adalah studi kualitatif, data diambil dari hasil uji coba kepada pengguna e-commerce yang melakukan uji coba terhadap aplikasi sistem pendukung keputusan. Sistem Pendukung Keputusan dibangun berdasarkan metode Simple Additive Weighting (SAW) sehingga pengguna dapat mengetahui peringkat alternatif dari platform e-commerce berdasarkan penilaian subjektif dari pengguna terhadap setiap alternatif.

\subsection{Sistem PendukungKeputusan}

Sistem pendukung keputusan adalah pendekatan sistematis terhadap masalah, mengumpulkan faktafakta yang menentukan peringkat dari alternatif yang dihadapi dan mengambil tindakan yang paling tepat [5]. Sistem pendukung keputusan adalah sistem berbasis komputer yang menghasilkan berbagai alternatif keputusan untuk membantu manajemen menggunakan data dan model untuk menangani masalah terstruktur atau tidak terstruktur [5]. Untuk menghasilkan keputusan yang baik ada beberapa tahapan proses yang harus dilalui dalam pengambilan keputusan. Proses pengambilan keputusan melalui beberapa tahap berikut [2]:

a. Tahap Penelusuran

Tahap ini pengambil keputusan mempelajari kenyataan yang terjadi, sehingga dapat mengidentifikasi masalah yang terjadi.

b. Tahap Desain

Pada tahap ini, pengambil keputusan mencari, mengembangkan dan menganalisis semua kemungkinan solusi, yaitu dengan membuat model yang dapat mewakili situasi masalah yang sebenarnya. Dari tahap ini didapatkan output berupa alternatif solusi.

c. Tahap Choice

Pada tahap ini, pengambil keputusan memilih salah satu alternatif solusi yang dikembangkan pada tahap desain, yang dipandang sebagai tindakan yang paling tepat untuk memecahkan masalah yang dihadapi. Dari tahap ini diperoleh solusi dan rencana implementasi

d. Tahap Implementasi 
Pengambil keputusan mengeksekusi serangkaian tindakan resolusi yang dipilih dalam fase seleksi. Keberhasilan implementasi dinyatakan dengan pemecahan masalahyang dihadapi, sedangkan kegagalan dinyatakan dengan adanya masalah yang masih berusaha untuk diatasi. Pada tahap ini akan diperoleh laporan implementasi solusi dan hasilnya.

\subsection{SimpleAdditive Weighting}

Dalam pembuatan program SPK ini digunakan suatu metode sistem pendukung keputusan SAW (Simple Additive Weighting) untuk menghasilkan peringkat dari alternatif yang ada berdasarkan dari kriteria-kriteria yang pilihannya ditentukan oleh pengguna.

Metode SAW sering juga dikenal istilah metode penjumlahan terbobot. Konsep dasar metode SAW adalah mencari penjumlahan terbobot dari rating kinerja pada setiap alternatif pada semua atribut. Metode SAW membutuhkan proses normalisasi matriks keputusan (X) ke suatu skala yang dapat diperbandingkan dengan semua rating alternatif yang ada [2].

Ada beberapa keuntungan dalam implementasi metode SAW diantaranya[1]:

a. Simple Additive Weighting (SAW) menyediakan model yang mudah dipahami dan fleksibel untuk berbagai masalah yang tidak terstruktur.

b. SimpleAdditiveWeighting(SAW) mencerminkancara berpikiralamiuntuk mengklasifikasikanelemen sistem ke dalam level yang berbeda dan mengelompokkan elemen serupa di setiap level.

c. Simple Additive Weighting (SAW) menyediakan metrik dan menyediakan metode untuk menentukan prioritas.

d. Simple Additive Weighting (SAW) memberikan penilaian konsistensi logis dari pertimbangan yang digunakan untuk menentukan prioritas.

e. Simple Additive Weighting (SAW) menuntun ke suatu pandangan menyeluruh terhadap alternatif yang muncul untuk masalah yang dihadapi.

f. Simple Additive Weighting (SAW) memberikan suatu sarana untuk penilaian yang tidak dipaksakan tetapi merupakan penilaian yang sesuai pandangan masing-masing.

g. Simple Additive Weighting (SAW) memungkinkan setiap orang atau kelompok untuk mempertajam kemampuan logic dan intuisinya terhadap persoalan yang dipetakan melalui Simple Additive Weighting (SAW).

Secara garis besar langkah-langkah penyelesaian masalah dengan metode simple additive weighting, adalah sebagai berikut [3]:

a. Menentukan kriteria-kriteria yang akan dijadikan acuan dalam pengambilan keputusan, yaitu Ci.

b. Menentukan rating kecocokan setiap alternatif pada setiap kriteria.

c. Membuat matriks keputusan berdasarkan kriteria (Ci), kemudian melakukan normalisasi matriks berdasarkan persamaan yang disesuaikan dengan jenis atribut atribut keuntungan ataupun atribut biaya sehingga diperoleh matriks ternormalisasi $R$.

d. Hasil akhir proses peringkat yaitu penjumlahan dari perkalian matriks ternormalisasi $\mathrm{R}$ dengan vektor bobot sehingga diperoleh nilai terbesaryang dipilih sebagai alternatif terbaik sebagai solusi.

\subsection{Theory of Planned Behavior}

Pembuatan program SPK ini didukung oleh jurnal penelitian terkait faktor penentu keputusan belanja di sebuah e-commerce yang ditulis oleh Dede Suleman [10]. Dalam penelitiannya ditemukan bahwa ada 3 dimensi yang menjadi dasar faktorfaktor penentu niat dan perilaku pengguna dalam menentukan keputusannya, diantaranya.

\section{Attitude Toward Behavior (dimensisikap)}

Disebutkan bahwa sikap terhadap suatu perilaku ditentukan oleh keyakinan mengenai konsekuensi dari suatu perilaku (behavioral beliefs). Hal ini dilakukan dengan cara menghubungkan antara perilaku tertentu dengan berbagai manfaat dan kerugian yang diperoleh jika individu melakukan atau tidak melakukan suatu perilaku. Keyakinan dapat memperkuat sikap individu terhadap perilaku itu apabila berdasarkan evaluasi yang dilakukan, didapat data bahwa perilaku dapat memberikan keuntungan baginya. (Ajzen dalam Suleman, 2018).

\section{Subjective Norm (dimensi norma subjektiit)}

Persepsi individu kepada harapan dari orang-orang yang berpengaruh dalam kehidupannya (significant others) mengenai hal yang dilakukan atau tidak dilakukannya. Norma subjektifjuga dipengaruhi oleh keyakinan. Bedanya adalah norma subjektif 
adalah fungsi dari keyakinan individu yang diperoleh atas pandangan orang-orang lain terhadap objek sikap yang berhubungan denganindividu (normative belief). (Ajzen dalam Suleman, 2018).

\section{Perceived behavioral control (dimensi kontrol perilaku)}

Persepsi kontrol perilaku ini, Ajzen membedakannya dengan pusat kendali yang dikemukakan (Rotter, 1990). Pusat kendali ini berkaitan erat dengan satu keyakinan individu yang relatif stabil dalam suatu keadaan. Persepsi kontrol perilaku bisa berubah dilihat dari situasi dan jenis perilaku yang akan dikerjakan. Pusat kendali berkaitan dengan keyakinan individu dengan keberhasilannya melakukan segala sesuatu tergantung pada usahanya atau tindakan diri sendiri atau atas faktor lain yang ada di luar dirinya.

\section{Hasil dan Pembahasan}

\section{Perencanaan Sistem}

Dalam pembuatan programDSSini dirumuskan 10 pertanyaan yang terbagiberdasarkan bobot yang terbagi di setiap dimensi faktor yaitu 40\% dimensi kontrol, 30\% dimensi norma subjektif dan 30\% dimensi sikap. Setiap dimensi diberikan masingmasing 4 dan 3 soal sehingga memenuhi keseluruhan bobot.

\section{PerhitunganSAW}

Setelah bobot setiap kriteria ditentukan diperlukan pengambilan data penilaian terhadap platform e-commerce yang diambil dari aplikasi SPK, yang selanjutnya dapat diproses untuk menghasilkan peringkat hasil berdasarkan metode SAW. Dalam proses membangun aplikasi dengan bahasa pemrograman javascript, penilaian pengguna disimpan dalam variabel berdasarkan alternatif dan kriteria yang dirangkai dalam array, selanjutnya data nilai setiap keputusan dinormalisasi dan diberibobot.

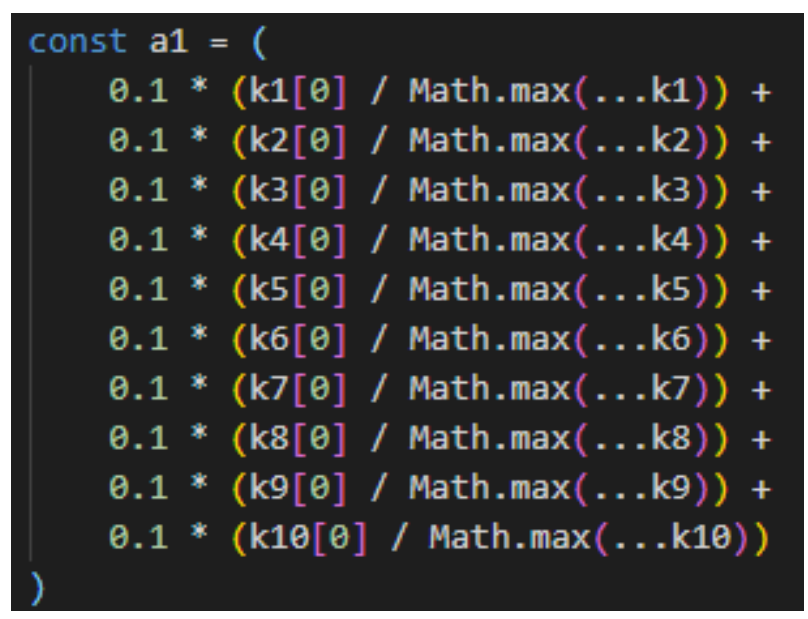

Gambar 1. Perhitungan SAW Pada Aplikasi

\section{Implementasi Aplikasi SPK}

Aplikasi dapat diakses dari https://ecommerce-dss.netlify.app/. pada halaman utama, pengguna dapat melihat 3 tombol navigasi utama di bagian atas, pengguna dapat mengakses mulai dari halaman utama, cara penggunaan, dan info seputar aplikasi. 


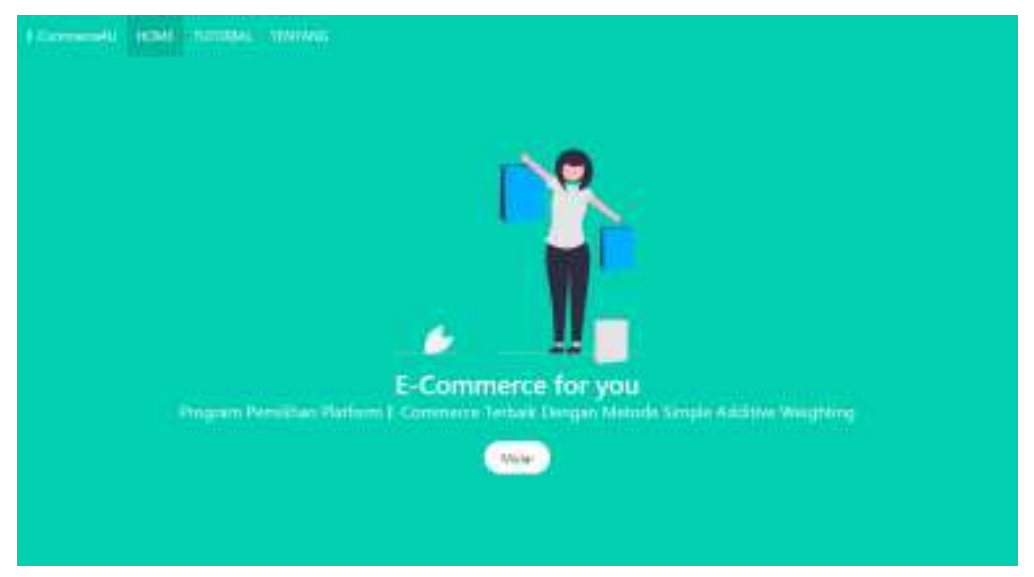

Gambar 2. Halaman Awal Aplikasi SPK

Untuk memulai menggunakan aplikasi, user dapat langsung menekan tombol "mulai" pada halaman awal web, lalu pengguna diperlukan untuk menginput nama dan email, ini diperlukan untuk mendata hasil uji coba yang selanjutnya akan dikirimkan ke database aplikasi.

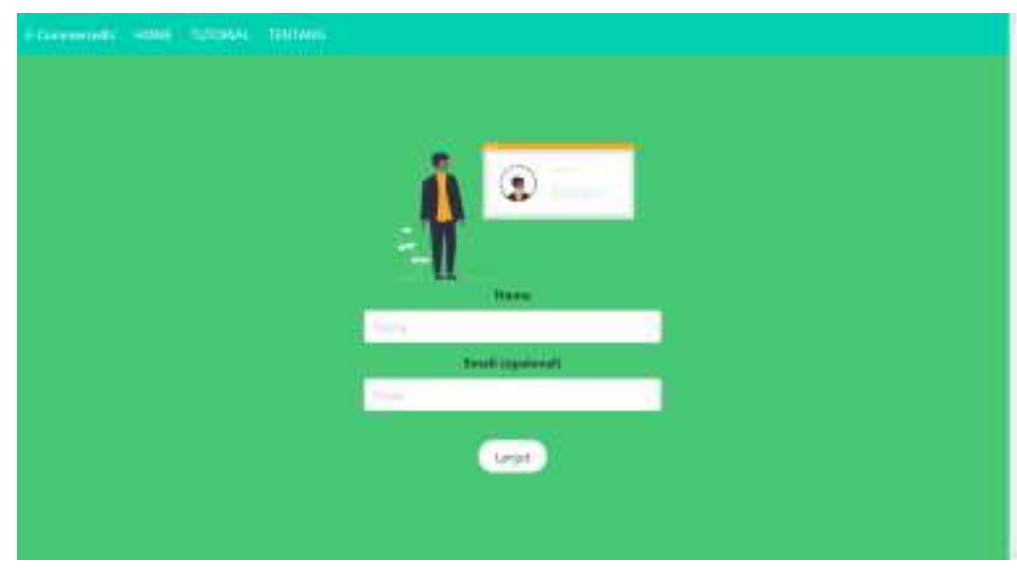

Gambar 3. Tahap Awal Penggunaan Aplikasi SPK

Selanjutnya pengguna dapat langsung memberikan penilaian terhadap 4 alternatif yang tersedia dengan memilih penilaian pada dropdown yang terbagi di setiap pertanyaan.

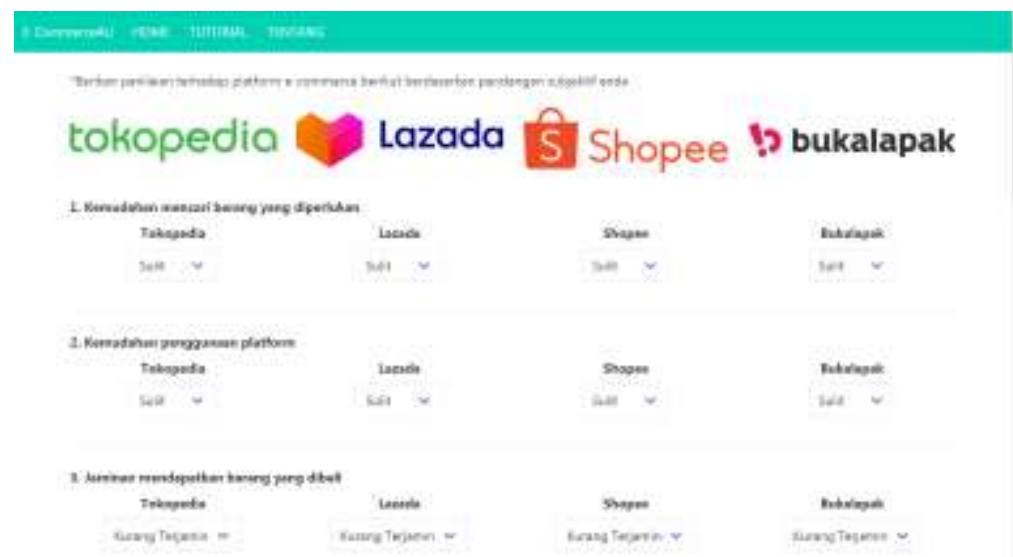

Gambar 4. Tahap Input Pengguna

Setelah pengguna mengisi semua penilaian terhadap setiap alternatif selanjutnya pengguna dapat menekan tombol submit, lalu hasil peringkat dari perhitungan SPK metode SAW dapat secara langsung terlihat. 


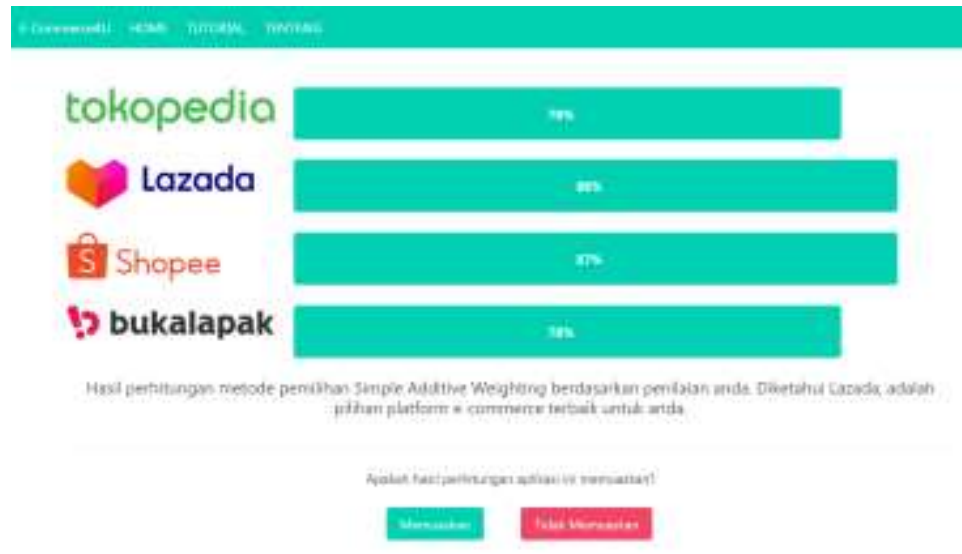

Gambar 5. Hasil Perhitungan SPK Metode SAW

Di akhir tahapan aplikasi SPK, pengguna diperlukan untuk mengisi survey kepuasan hasil dari perhitungan aplikasi SPK yang dibuat, hasil survey ini akan disimpan pada database aplikasi dengan tujuan sebagai bahan evaluasi dari aplikasi SPK yang dibuat.

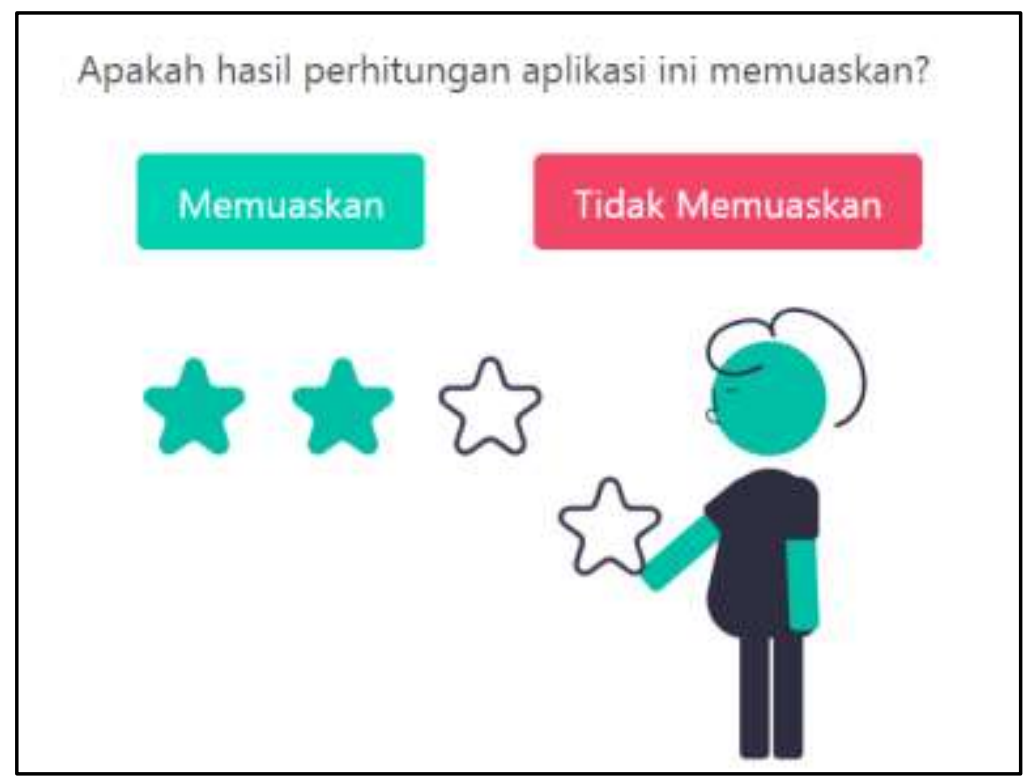

Gambar 6. Survey Kepuasan Hasil

\section{Hasil Uji coba}

Aplikasi sistem pendukung keputusan diuji coba kepada 30 responden yang memiliki pengetahuan terkait platform e-commerce sebagai kebutuhan belanja secara online, responden diperlukan untuk mencoba aplikasi SPK dengan menjawab pertanyaan survey yang sudah dirumuskan berdasarkan 3 dimensi faktor penentu perilaku dan keputusan pengguna. Setelah responden mengisi keseluruhan survey maka peringkat alternatif dari hasil perhitungan SPK dengan metode SAW akan terlihat oleh responden, hasil peringkat alternatif dihitung dengan SPK metode SAW berdasarkan dari penilaian subjektif pengguna terhadap alternatif yang ada, namun hasil perhitungan tentu tidak mungkin 100\% akurat maka di akhir penggunaan aplikasi SPK responden dapat memberikan penilaian terhadap hasil perhitungan SPK, lalu hasil ini akan diunggah pada database aplikasi SPK sehingga dapat dilihat hasil keseluruhan uji cobanya adalah sebagai berikut.

Tabel 1. Responden uji coba pengguna SPK 


\begin{tabular}{|c|c|c|c|c|c|c|}
\hline id Nama & Email & Tokopedia & Lazada & Shopee & Bukalapak & Kepuasan \\
\hline 1 andra & andragunegmail.com & 8000 & 80.00 & 7333 & 70.00 & True \\
\hline 2 Nadiani & & 96.67 & 76.67 & 73.33 & 90,00 & True \\
\hline 3Fardan Barkah Ajbari & fardanbarkah@upi.edu & 9000 & 66.67 & 03.33 & 68.33 & True \\
\hline 4Faishal Nut Alim & faishalnuralimesupi.edu & 93.33 & 70.00 & 100,00 & 73.33 & True \\
\hline 5.Prabhangkara Aceli Prayoga & adhip659agrupi.edu & 83.2a & 76.67 & 96.67 & 71.67 & True \\
\hline 6Muhammad Ali Afzaluhlhag & aliatzalulhaq pupi.erfu & 83.33 & 63.33 & B0.00 & 63.33 & True \\
\hline 7 Hasnan Abdul Hakim & hasnanabctulthakim@upi.edu & 100,00 & 7333 & 03.33 & 56.67. & True \\
\hline Bhilumy & & 90,00 & 40,00 & 86.67 & 36.67 & True \\
\hline QSekar Nurul & Sekemuniftegfgmalcom & 76.67 & 35.00 & 10000 & 41.67 & True \\
\hline 10Rizki Cahya lskandar & cahyarizkiskanda & 86.67 & 83.33 & 100.00 & e3.33 & True \\
\hline 11 Ai Rałmat & ali.rahmatglapi.edu & 95.00 & 93.39 & 06.67 & 81.67 & True \\
\hline 12Dara & & 100,00 & 93.33 & 03.33 & 93.33 & False \\
\hline 13 Nund khofifah augustanngrum & nurulkhottah5 forpmailcom & 9000 & 6667 & 83.33 & 73.33 & True \\
\hline 14 Putri indryani & putriedriyanigupiedu & 100.00 & 96.67 & 96.67 & 90.00 & True \\
\hline 15 Elsya & & 0000 & 70.00 & 100.00 & 73.33 & True \\
\hline 16Rifa & rifahlianifa30øupi.edu & 9000 & 80,00 & 81.67 & 90.00 & True \\
\hline 17 Eva Afifa & & 90.00 & 96.67 & 10000 & 90.00 & True \\
\hline 18Fizky & Ficky.anandaßupiedu & 9500 & 83.33 & 03.33 & 83.33 & True \\
\hline 19rizal chan & & 83.33 & 61.67 & 70.00 & 65,00 & True \\
\hline 20 Muhammad Aziz & muzazogupiedu & 93.33 & 90,00 & 100.00 & 90.00 & True \\
\hline 21 Syaritah Nuraini & & 96.67 & 70.00 & 93.33 & 66.67 & True \\
\hline 22 ridwan & & 91.87 & 78.39 & 93.33 & 78.33 & True \\
\hline $23 \mathrm{M}$ Hadi Naufal H & tradinautalgupi.edu & 100.00 & 90.00 & 00.00 & 96,67 & True \\
\hline 24 awan & thechainsmokersegmail.com & 93.33 & 100.00 & 93.33 & 93.33 & True \\
\hline 25. Jut & & 96.67 & 80,00 & 10000 & 86.67 & True \\
\hline $26 \mathrm{Adi}$ & & 48,33 & 93.33 & 58.33 & 75.00 & True \\
\hline 27 Azka Nabilah & nazkanabila gegmaj.com & 50.00 & 43.39 & 100.00 & 56.67 & True \\
\hline 28wini & wwatiasarifgmail.com & 7500 & 76.67 & 06.67 & 72.67 & True \\
\hline 29 edo & edotido@gmait.com & 100,00 & 40,00 & 83.33 & 43,33 & True \\
\hline 30hasan & & 81.67 & 61.67 & 65.00 & 66.67 & True \\
\hline
\end{tabular}

Dari hasil uji coba kepada 30 responden pengguna e-commerce diketahui aplikasi yang dibuat dapat memberikan peringkat yang akurat pada setiap alternatif e-commerce berdasarkan perhitungan kriteria yang berdasar dari 3 dimensi faktor yang menentukan konsumen dalam memilih platform e-commerce.

\section{Simpulan}

Berdasarkan dari hasil uji coba kepada 30 responden menghasilkan ketepatan perhitungan SPK sebesar 96.67\%. Dari angka tersebut dapat disimpulkan bahwa program yang dibangun cukup layak digunakan untuk membantu pengguna mengetahui platform e-commerce yang terbaik yang digunakan, berdasarkan dari 3 dimensi faktor yang menentukan perilaku pengguna dalam memilih keputusan belanja online di platform ecommerce. Dari hasil yang didapat juga diketahui bahwa setiap pengguna e-commerce dapat menyukai lebih dari satu platform maka dapat diketahui bahwa setiap platform e-commerce yang ada dipastikan memiliki keunggulan masing masing yang dapat memberikan daya tarik kepada target pengguna yang berbeda-beda.

\section{Daftar Pustaka}

1. Djamain, Y. (2015). Sistem pendukung keputusan penerimaan pegawai baru pt. pln (persero) kantor pusat dengan menggunakan metode simple additive weighting (saw). Jurnal Teknik Informatika, 8(1).

2. Eniyati, S. (2011). Perancangan sistem pendukung pengambilan keputusan untuk penerimaan beasiswa dengan metode SAW (Simple Additive Weighting). Dinamik, 16(2).

3. Fitriyani, N., \& Ipnuwati, S. (2017). SISTEM PENDUKUNG KEPUTUSAN DALAM MENENTUKAN KETUA OSIS MENGGUNAKAN SIMPLE ADDITIVE WEIGHTING (SAW)(STUDI KASUS: MTsN MODEL TALANGPADANG). Prociding Kmsi, 5(1).

4. HTS, D. I. G., \& Harahap, S. Z. (2020). SPK Untuk Pemilihan Kepala Sekolah Menggunakan Metode Saw dan Profile Matching. U-NET Jurnal Teknik Informatika, 4(1), 7-12.

5. Larasati, A. A., Utami, A. S. F., \& Prasetyo, F. (2020). Sistem Pendukung Keputusan Dalam Pemilihan Belanja Online Marketplace Menggunakan Analytic Network Process (ANP). INFORMATICS FOR EDUCATORS AND PROFESSIONAL: Journal of Informatics, 4(2), 133142.

6. Mahendra, G. S., \& Aryanto, K. Y. E. (2019). SPK Penentuan Lokasi ATM Menggunakan Metode AHP dan SAW. Jurnal Nasional Teknologi dan Sistem Informasi, 5(1), 49-56. 
7. Permana, F. C., Sutisna, M. R., Prawatya, A. K. S., Sylviani, S., \& Wiriadikusumah, A. N. Rancang Bangun Sistem Informasi Display Jadwal Perkuliahan Kampus UPI di Cibiru Berbasis Web. INTEGRATED (Journal of Information Technology and Vocational Education), 2(1), 8-14.

8. Shalih, P. R., \& Irfansyah, I. Perancangan Game Berbasis Multimedia Development Life Cycle (MDLC) Tentang Tokoh Pahlawan Indonesia Masa Kini untuk Generasi Z. Edsence: Jurnal Pendidikan Multimedia, 2(2), 83-92.

9. Sari, I. P., Kartina, A. H., Pratiwi, A. M., Oktariana, F., Nasrulloh, M. F., \& Zain, S. A. Implementasi Metode Pendekatan Design Thinking dalam Pembuatan Aplikasi Happy Class di Kampus UPI Cibiru. Edsence: Jurnal Pendidikan Multimedia, 2(1), 45-55.

10. Suleman, D. (2018). Faktor penentu keputusan konsumen Indonesia memilih tempat belanja disebuah e-commerce (Theory of Planned Behavior). Jurnal Doktor Manajemen, 1, 1-9.

11. Utomo, R. G., \& Rosmansyah, Y. (2020). Framework untuk Mendesain Sistem Massive Open Online Courses (MOOCs) untuk Universitas di Indonesia. Edsence: Jurnal Pendidikan Multimedia, 2(2), 65-74. 